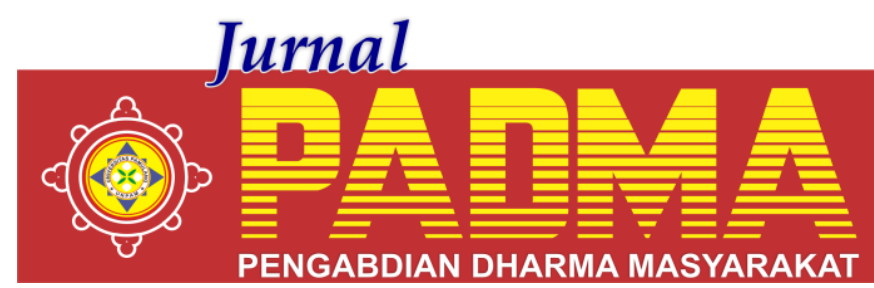

VOLUME 1, NOMOR 3, JULI 2021

\title{
SOSIALISASI EFEKTIFITAS MANAJEMEN SUMBER DAYA MANUSIA PADA YAYASAN PEMBANGUNAN MASYARAKAT SEJAHTERA (YPMS) PAMULANG TANGERANG SELATAN
}

\author{
${ }^{1 *}$ Muhamad Fahrul Fahroji, ${ }^{2}$ Lukmanul Hakim, 3Pniel Adil Azza Gulo, ${ }^{4}$ Nardi Sunardi, \\ 5Boedi Hasmanto \\ Universitas Pamulang, Tangerang Selatan, Banten, Indonesia \\ *fahrulfahroji.m@gmail.com
}

\begin{abstract}
Abstrak
Kegiatan pengabdian kepada masyarakat ini bertujuan untuk memberikan sosialisasi sekaligus menyampaikan perkembangan sumber daya manusia dimana tidak hanya ada di dunia perusahaan saja, dalam dunia pendidikan atau yayasan pun ada yang namanya pengembangan sumber daya manusia, dikarenakan tekanan global dan perubahan yang begitu cepat seakan mengharuskan masing-masing lembaga/yayasan secara total dan menyeluruh mendekatkan pada masalah pengembangan sumber daya manusia. Melakukan pelatihan untuk menghasilkan tenaga terampil serta menciptakan pendidikan yang berkualitas saat ini adalah hal yang sangat penting dibanding sebelumnya, Karena dalam era ini iklim kompetisi yang tinggi di segala bidang yang menuntut Lembaga/Yayasan untuk bekerja dengan lebih efektif dan efesien. Tingkat kompetisi yang tinggi menuntut pula suatu organisasi mengoptimalkan sumber daya manusia yang dimilikinya, hal ini disebabkan oleh pengaruh yang kuat dari sumber daya manusia terhadap efektivitas dan efesiensi organisasi.
\end{abstract}

Kata Kunci: Sumber Daya Manusia, Yayasan, Efektivitas

\section{Abstract}

This community service activity aims to provide socialization as well as convey the development of human resources which is not only in the corporate world, in the world of education or foundations there is such a thing as human resource development, due to global pressures and rapid changes that seem to require each individual each institution/foundation is totally and comprehensively closer to the problem of human resource development. Conducting training to produce skilled workers and creating quality education is now more important than ever, because in this era the climate of high competition in all fields requires Institutions/Foundations to work more effectively and efficiently. The high level of competition requires an organization to optimize its human resources, this is due to the strong influence of human resources on the effectiveness and efficiency of the organization.

Keywords: Human Resources, Foundation, Effectiveness

\section{PENDAHULUAN}

Menurut psikologi sosial suatu pengantar (Prof.Dr. Bimo walgito 2003: 111 ) Menurut teori model kontigensi, efektivitas kepemimpinan disamping ditentukan oleh tinggi rendahnya Aso/LPC dari pemimpin juga ditentuan oleh situasi tugas (tasksituation). Efetivitas adalah hasil kerja kelompok dalam mencapai tujuannya. Makin dekat hasil kelompok dengan tujuannya, maka makin efektif pemimpin kelompok tersebut. Upaya pemimpin mendorong para pengikutnya dilakukan setelah semua betulbetul yakin dan percaya bahwa gerakan karyawan kearah leadership adalah menguntungkan bagi organisasi.

Pada awalnya sumber daya manusia adalah terjemahan dari kata "human resources" namun ada pula para ahli menyamakan sumber daya manusia dengan "manpower" atau tenaga kerja.Bahkan ada beberapa pihak yang menyetarakan sumber daya manusia dengan personal (personal, Sumber daya manusia merupakan salah satu sumber daya yang memiliki akal perasaan dan keinginan dan keterampilan, pengetahuan, dorongan, daya, dan karya (rasio rasa dan karsa). Semua potensi sumber daya manusia tersebut berpengaruh 
terhadap upaya organisasi dalam mencapai tujuan. Meskipun kemajuan teknologi mencapai puncak tertinggi perkembangan informasi yang semakin meluas dan tersedianya modal dan memadainya bahan, Namun tanpa adanya sumber daya yang mempunyai, maka sebuah organisasi akan sulit mencapai tujuannya Menurut Wibowo (2007:165) sumber daya manusia dalam setiap organisasi, meskipun telah melalui tahap seleksi yang baik namun dalam pelaksanaan tugas dan tanggung jawabnya masih selalu menghadapi persoalan yang tidak dapat di selesaikannya sendiri. Oleh karena itu perlu dilakuka segala usaha tindakan yang berhubungan langsung dengan perencanaan, penyusunan, pembangunan, pengembangan, pengarahan, penggunaan serta pengendalian segalasegala suatu secara bersama. Berikut ini adalah beberapa pengertian sumber daya manusia menurut para ahli : Weater dan davis (1996 :166), memberikan pengertian sumber daya manusia sebagai pegawai yang siap mampu siap dan siaga dalam mencapai tujuan-tujuan organisasi.Sebagaimana dikemukakan, bahwa dimensi pokok sisi sumber daya adalah konstribusinya terhadap organisasi, sedangkan dimensi pokok manusia adalah perlakuan konstribusinya terhadapnya yang pada gilirannya akan menentukan kualitas dan kapabilitas hidupnya. Berdasarkan definisi sumber daya manusia diatas, maka kita harus memahi bahwa sumber daya manusia harus diartikan sebagai sumber dari kekuatan yang berasal dari manusia-manusia yang dapat didaya gunakan oleh organisasi. Dengan berpegang pada pengertian sumber daya manusia tersebut, maka istilah sumber daya manusia adalah manusia bersumber daya dan merupakan kekuatan (power).

Yayasan Pembangunan Masyarakat Sejahtera adalah merupakan salah satu lembaga sosial kemanusian yang berada di wilayah Kecamatan Pamulang dengan aktivitas utama sebagai Yayasan sosial dalam bentuk pembinaan terhadap anak-anak yatim/piatu dan kaum dhuafa melalui instrumen program penyantunan panti, pendidikan Terpadu (SD, SMP dan SMA), dakwah, pemberdayaan ekonomi dan rehabilitasi mental. Saat ini total santri yang berada di YPMS sekitar 100 orang, tentu saja diperlukan biaya operasional yang cukup besar untuk membiayainya.

Saat ini pendanaan YPMS berasal dari berbagai sumber baik dari pemerintah, Baznas, BOS, LSM dan donatur tidak tetap lainnya. Untuk menjaga keberlangsungan Yayasan yang sudah berdiri sejak tahun 1989 tersebut diperlukan pengelolaan sumber dana yang baik dengan menjaga hubungan baik dengan para donatur yang selama ini sudah menyumbang. Dalam era ini iklim kompetisi yang tinggi di segala bidang yang menuntut Lembaga/Yayasan untuk bekerja dengan lebih efektif dan efesien. Tingkat kompetisi yang tinggi menuntut pula suatu organisasi mengoptimalkan sumber daya manusia yang dimilikinya, hal ini disebabkan oleh pengaruh yang kuat dari sumber daya manusia terhadap efektivitas dan efesiensi organisasi.

Manusia merupakan sumber daya yang paling penting dalam usaha organisasi mencapai keberhasilan. Sumber daya manusia ini menunjang organisasi karya, bakat, kreativitas dan dorongan. Berapapun sempurnanya aspek teknologi dan ekonomi, tanpa aspek manusia sulit untu mencapai tujuan-tujuan. Peran Lembaga/Yayasan yang didalamnya ada pembinaan pendidikan serta sosial kemanusian merupakan sarana strategis untuk meningkatkan kualitas dan harkat manusia juga sebagai tolak ukur martabat suatu bangsa. Tolak ukur kualitas suatu bangsa, dapat dilihat dari sejauh mana keberhasilan pelaksanaan sosial kemanusian dan pendidikan. Salah satu dari banyaknya persoalan sosial dan pendidikan yang dihadapi bangsa Indonesia adalah rendahnya mutu aksi sosial dan pendidikan pada setiap jenjang.

Manajemen sumber daya manusia sangat penting bagi sosial dan pendidikan dalam mengelola, mengatur, dan memanfaatkan tenaga pendidik sehingga dapat berfungsi secara produktif untuk mencapai suatu tujuan. Pengelolaan sumber daya manusia ditempatkan sebagai unsur penting dalam organisasi. Dalam aspek manajemen SDM akan menghasilkan kinerja perusahaan yang tinggi tanpa menyampingkan aspek-aspek lainnya. Perencanaan Sumber Daya Manusia merupakan bagian terpenting yang harus dilaksanakan dalam organisasi. Perencanaan 
SDM adalah langkah tertentu yang diambil oleh manajemen agar dapat menjamin bahwa bagi organisasi tersedia tenaga kerja yang tepat untuk menduduki manajemen SDM dan sebagai kontributor pada proses perencanaan strategis organisasi, mengingat perencanaan SDM tidak hanya membantu organisasi dalam menentukan sumber daya manusia yang diperlukan untuk mencapai tujuan, tetapi juga menentukan yang benarbenar di capai dalam sumber daya manusia yang tersedia. Dampaknya akan sangat menguntungkan bagi organisasi karena mengurangi unsur ketidakpastian.

\section{METODE}

Melihat permasalahan yang dihadapi maka langkah-langkah yang dilakukan untuk mencapai tujuan dan sasaran kegiatan ini maka diadakan pendekatan kepada instansi terkait yaitu YPMS Pamulang melalui penjelasan mengenai Efektivitas Sumber Daya Manusia pada Yayasan Pembangunan Masyarakat Sejahtera (YPMS), sebagai upaya untuk membantu yayasan terkait dalam proses mengatur dan mengelola sumber daya manusia yang lebih baik lagi. Pengabdian kepada masyarakat (PKM) dilakukan pada bulan oktober tahun 2020. Kegiatan ini akan dibimbing oleh tim pelaksana staf-staf pengajar dari Universitas Pamulang dengan mengikut sertakan peran YPMS Pamulang.

Untuk melaksanakan kegiatan sosiaalisasi ini, prosedur kerjanya sebagai berikut :

a. Tahap Persiapan, Tahap persiapan yang dilakukan meliputi :

- Survei awal, Pada tahap ini dilakukan survei lokasi di desa Kedaung, Kec.Pamulang Kota Tangerang Selatan Banten

- Observasi. Setelah survei maka ditentukan pelaksanaan dan sasaran peserta kegiatan

- Rapat Koordinasi Tim. Pada tahap ini rapat mengenai pembagian tugas, membuat jadwal pelaksanaan, mulai dari persiapan, pelaksanaan, sampai evaluasi dan penyusunan laporan

b. Tahap Evaluasi, Tahap evaluasi merupakan penilaian setelah rangkaian kegiatan dilakukan oleh pelaksana sesuai dengan jadwal yang telah ditentukan.
Evaluasi ini bisa berupa perbaikan atau saran untuk pelaksanaan kegiatan lebih baik lagi dan kelanjutan menjadi binaan kampus.

c. Partisipasi Mitra dalam Pelaksanaan Program

Partisipasi mitra dalam pelaksanaan program PKM ini sangat kooperatif dengan memberikan ijin kepada tim untuk melaksanaankan pengabdian Yayasan binaan kampus, memberikan keterangan baik berupa informasi atau data-data yang dibutuhkan sampai rencana pelaksanaan berupa kegiatan pelatihan/pendampingan nantinya. Dalam pengembangan sarana prasarana yang diperlukan partisipasi mitra dan pemda/lembaga terkait juga.

\section{HASIL DAN PEMBAHASAN}

Kegiatan Pengabdian Kepada Masyarakat (PKM) dilakukan di YPMS Pamulang kota Tanggerang Selatan provinsi Banten, Sosialisasi Efektivitas Sumber Daya Manusia untuk yayasan. Universitas pamulang membuka diri untuk melakukan pengabdian kepada masyarakat dengan berbagai pihak dalam rangka pengembangan ilmu, institusi, teknologi dan seni dalam rangka pelaksanaan Tri Dharma Perguruan Tinggi yakni Pendidikan, Penelitian dan Pengabdian.

UNPAM sudah mempunyai jaringan dengan berbagai lembaga lain yakni pemerintah pusat, pemerintah propinsi, pemerintah kabupaten, dunia usaha, swasta maupun dengan masyarakat. Lokasi kampus yang tidak begitu jauh dari dari YPMS Pamulang menjadi salah satu faktor penting dalam pelaksanaan kegiatan PKM ini dan sudah menjadi kewajiban bagi perguruan tinggi untuk ikut serta membantu berbagai persoalan yang dihadapi masyarakat. Sudah selayaknya kehadiran perguruan tinggi agar dapat benar-benar dirasakan manfaatnya oleh masyarakat baik yang dekat lokasinya dengan kampus / perguruan tinggi.

Pertama kali kami melakukan survey lokasi yang akan dijadikan tempat untuk pengabdian kepada masyarakat di Lokasi yang dijadikan tempat kegiatan Pengabdian Kepada Masyarakat (PKM) adalah YPMS Pamulang Kota Tanggerang Selatan. Kemudian dilanjutkan dengan pengajuan 
proposal pengabdian kepada masyarakat dengan judul SOSIALISASI EFEKTIVITAS SUMBER DAYA MANUSIA PADA YAYASAN PEMBANGUNAN MASYARAKAT SEJAHTERA (YPMS) PAMULANG TANGERANG SELATAN, Setelah proposal disetujui, kami melakukan persiapan materi dan bahan-bahan yang akan digunakan dalam kegiatan ini. Persiapan ini dilakukan agar siswa dapat dengan mudah memahami materi yang kami berikan. "Sosialisasi Evektivitas Sumber Daya Manusia pada YPMS Pamulang Kota Tanggerang Selatan Provinsi Banten" Yayasan merupakan organisasi non pemerintah yang beraktifitas diluar struktur politik yang terinstitusionalisasi dan merupakan entitas jasa sukarelawan yang bertujuan untuk membantu sesama dalam mengurangi masalah sosial. Berdasarkan Undang - Undang No 16 tahun 2001, yayasan adalah badan hukum yang terdiri atas kekayaan yang dipisahkan dan diperuntukkan dalam mencapai tujuan tertentu dibidang sosial, keagamaan dan kemanusiaan yang tidak mempunyai anggota.

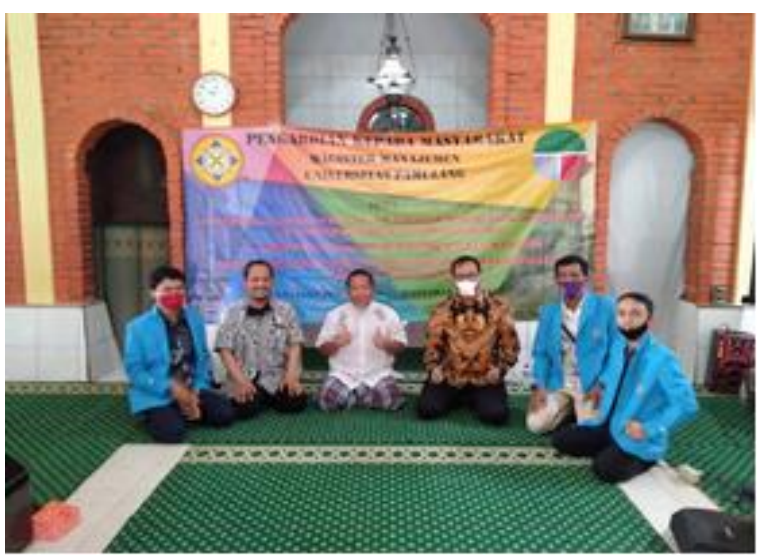

Gambar 1. Foto Bersama Dosen pendamping, mahasiswa PKM dan Pengelola Yayasan

\section{PENUTUP}

Pengabdian masyarakat ini belum sepenuhnya mampu mencapai tujuan sesuai dengan yang ditetapkan, tetapi kegiatan penyuluhan ini telah memberikan kontribusi positif sebagai upaya pengembangan efektivitas sumber daya manusia bagi yayasan. Pembina dan Staff sudah dibekali dengan ilmu sumber daya manusia serta sarana prasarana untuk mewujudkan hal tersebut.

Pengabdian kepada masyarakat (PKM) pada YPMS Pamulang Kota Tanggerang Selatan Provinsi Banten Yaitu :

1. Memberikan pengetahuan dalam hal mengelola, mengatur, dan memanfaatkan tenaga pendidik sehingga dapat berfungsi secara produktif.

2. Memberikan pengetahuan tentang Efektifitas Manajemen Sumber Daya Manusia di Yayasan Pembangunan Masyarakat Sejahtera.

3. Memberikan pengetahuan bagaimana menjaga dan mengembangkan kemitraan.

\section{DAFTAR PUSTAKA}

A. Anwar Prabu Mangkunegara, Manajemen Sumber Daya Manusia Perusahaan, PT Remaja Rosdakarya: Bandung, 2009.

Akbar, I. R., Sunarsi, D., Salami, M. M., Sarwani, S., \& Catio, M. (2021). Peningkatan Minat Wirausaha Pada Siswa SMK Muhammadiyah Parung Kabupaten Bogor. Jurnal PADMA: Pengabdian Dharma Masyarakat, 1(2).

Dewanti, R. N., Supriyadi, E., Sofyan, S., Sunarsi, D., Rachmansyah, B. A., \& Yani, A. (2021). Penyuluhan Dan Pelatihan Keterampilan Sablon Pigment Pasta Manual Di Karang Taruna 03 Desa Cisauk. Jurnal PADMA: Pengabdian Dharma Masyarakat, 1(1).

Kadarisman, Manajemen Pengembangan Sumber Daya Manusia, Rajawali Pers, Jakarta : 2013.

Marihot Tua Efendi Hariandja, Manajemen Sumber Daya Manusia, Jakarta: PT Gramedia Widiasarana, 2002

Muchlisin Riadi, Kajian Pustaka.com, 20122016, di akses tanggal 12 Desember 2016 pukul 10:14 wib (http://www.kajianpustaka.com/2012 $\not 11 /$ def inisi-fungsi-dan-bentukkeluarga.html).

Nasrudin DanLusi "Psikologi Pendidikan" 2016 di akses tanggal 1 Desember 2016 pukul 1:35). (http://nasrudinnnl.blogspot.co.id/20 14/10/psikologipendidik anmuhibbin-syah.html). 